\title{
Anatomy in Nazi Germany: The Use of Victims' Bodies in Academia and Present-Day Legacies
}

\author{
Sabine Hildebrandt, M.D.
}

After decades of denial, German academic medicine was reluctant to accept responsibility for its complex collaboration with the Nazi regime. Consequently, much of this history needs further detailed exploration, as legacies from this history still exist in the form of "Books, Bones and Bodies." Specifically, this concerns the legacies of anatomists' use of bodies of Nazi victims in teaching and research, as "data" have become anatomical knowledge and specimens from victims continue to be discovered.

OPEN ACCESS

Libertas Haas-Heye and Harro Schulze-Boysen were married in Berlin, Germany, in 1936. Libertas was a publicist in the movie industry, and Harro an officer in the Department of Aviation in the Reichs government of National Socialist Germany. They were opposed to Hitler and his party, and worked together with other dissidents in a group that later became known as the socalled "Red Orchestra". In August 1942 their group was discovered, and Harro and Libertas were sentenced to death for high treason on 19 December 1942.

Prisoners on death row were allowed to write a letter of farewell. Libertas addressed hers to her mother and voiced clear ideas of what should happen to her body after her death.

"As a last wish, I have asked that my 'material substance' be left to you. If possible, bury me in a beautiful place amidst sunny nature."

However, her wishes were not heeded.
Instead, the following happened, as remembered in a report by Charlotte Pommer, a young physician scientist, who worked as assistant to Herman Stieve, the Chair of Anatomy in Berlin:

"On 22nd of December 1942 eleven men were hanged and five women decapitated. Fifteen minutes later they were laid out on the dissection tables in the anatomical institute. [She] lay on the first table, [...] on the third table the big lifeless body of her husband [...] I felt paralyzed and could hardly assist Professor Stieve, who - as always-carried out his scientific exploration with great care and uncommon diligence [...] After the impressions of that night I resigned from my position" (Orth, 2013).

Herrmann Stieve remained at the Berlin Institute until his death in 1952, continuously because he was not a member of the NSDAP, the National Socialist [Nazi] party. He dissected several hundred bodies of the executed, as he noted in his publications. Before 1920 he started with animal experiments in which he studied the influence of the nervous system and stress on the male and female reproductive system. In the 1920s he realized that the situation of death row candidates reflected his animal design, in that imprisonment fear of execution could be seen as stressors. Thus, he investigated the reproductive organs of executed men in the 1920s. Women were not executed during this time. However, as soon as bodies of executed women became available in 1935, he used them for his studies on the influence of severe psychological trauma on their menstruation patterns and the morphology of their reproductive organs. As far as is known, he had no contact with prisoners before their death. He received clinical information from prison personnel.

To get closer to an understanding of the fate of Libertas Schulze-Boysen and the actions of Hermann Stieve and other anatomists, one has to look at the various facets of Anatomy during National Socialism, which include: 
- the relationship between anatomists and politics

- the anatomical body procurement and the ways it changed after 1933

- the influence of these changes in body procurement on anatomical education and research

- and the stages of ethical transgressions that consequently ensued in the anatomical sciences.

- Finally, the continuities of this history into the present need to be considered.

After the National Socialist regime came to power in January 1933, one of its first goals was the reorganization of the universities. Leadership of the universities was taken away from the individual German states and centralized within the Ministry of Education in Berlin, which was also responsible for the anatomical institutes. This included research funding, recruitment of faculty, and the professional society, the Anatomische Gesellschaft. In terms of the body procurement, the Ministry of Education shared this responsibility with the Ministry of Justice, when bodies from prisons and executions were concerned. All science was to be aligned with NS doctrine and to be utilized for war purposes. Within 3 months laws were instituted that led to the dismissal of all so-called "non-Aryan" and politically opposed faculty and students. According to Gruettner and Kinas, about $20 \%$ of the faculty present at German universities in 1933 were dismissed over the following years. In terms of anatomy we see that 54 of 176 anatomists for whom we have political data saw their career disrupted for socalled "racial" or political reasons, whereby this dismissal meant anything from forced change of jobs to forced emigration and incarceration, and of the remaining 122, 99 joined the NSDAP (Hildebrandt, 2016).

One of the active National Socialists was the Austrian Eduard Pernkopf. He became chair of anatomy at Vienna University in 1933 and joined the NSDAP and SA in 1933/34. After the so-called "Anschluss" he was made dean of the medical school in March 1938. In this

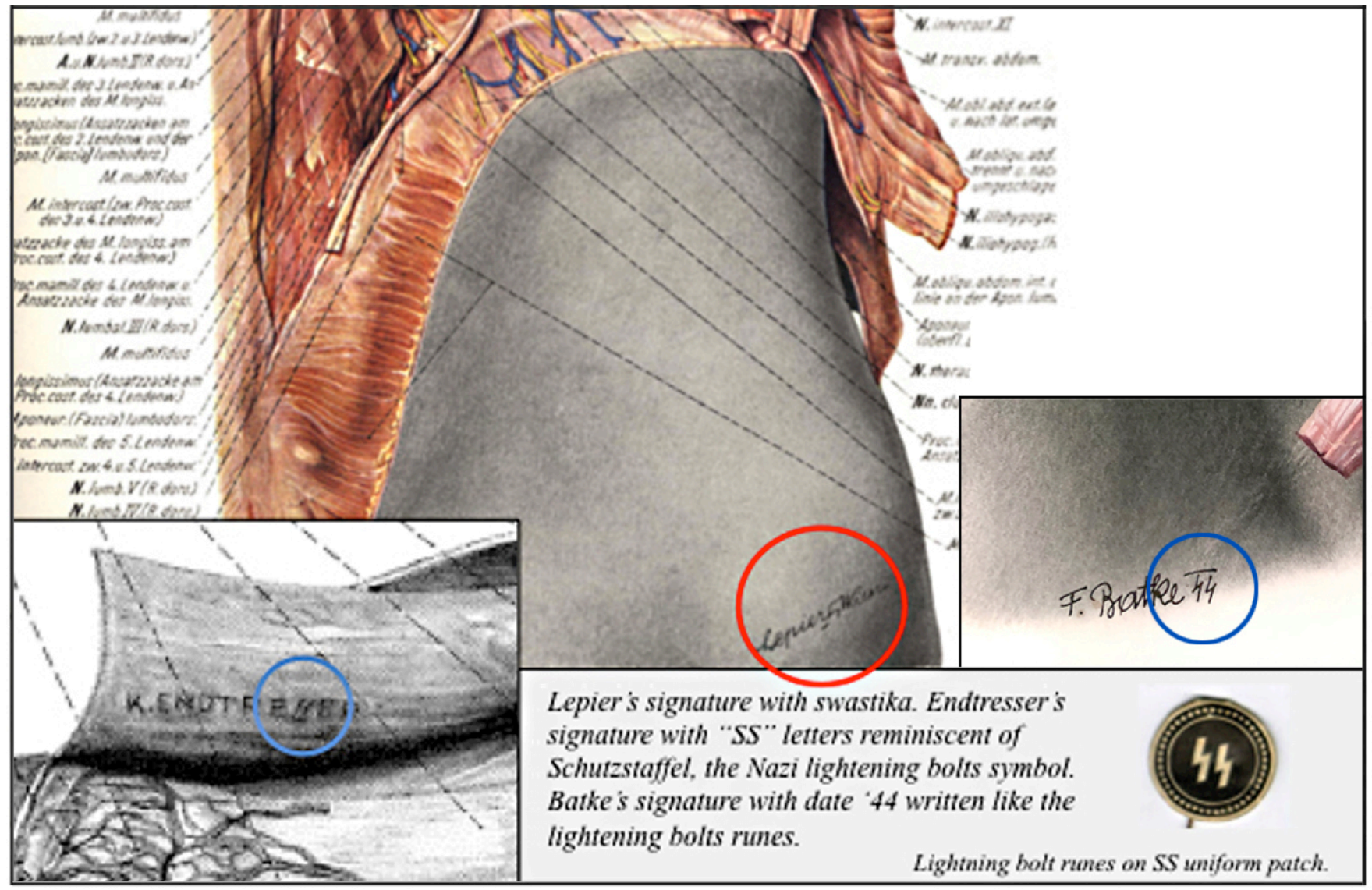

Figure 1. Swastika seen in Erich Lepier's signature, and the double SS (of the SS runes) seen in Karl Endtresser's and Franz Batke's signature. Image credits: Medical University of Vienna, MUV-Andruck-336ll-Seite1, MUW-Andruck181ll-Seite1, MUWZE-003250-0005-0538r. 
capacity he oversaw the removal of $53 \%$ of the medical faculty for "racial" or political reasons. In 1943 he also became "Rektor" or President of Vienna University, and in 1945 was one of the few anatomists who lost their academic position permanently. Nevertheless, he was well known after the war because he authored an atlas of topographical anatomy, which was popular especially among anatomists and surgeons because of the great detail and a new printing technique that enabled brilliant images. The first researchers to look into the origin of the atlas were Gerald Weissmann and David Williams in the 1980s (Weissman, 1987; Williams, 1988).

It took apparently half a century before the users of the atlas noticed or asked in more detail about the illustrators, who had left signs of their National Socialist sympathies in the images during the war years. You see the Swastika in Erich Lepier's signature, and the double SS of the SS runes in Karl Endtresser's and Franz Batke's signature in Figure 1.

In 1996 an international inquiry by Yad Vashem, initiated by New York oral surgeon Howard Israel and Canadian physician and medical historian Bill Seidelman, was sent to the University of Vienna (Israel and Seidelman, 1996). In the following Senatorial Project it was confirmed that Pernkopf was indeed an avid National Socialist, and it was ascertained that the bodies of many National Socialist victims had been delivered to the anatomical institute, among them more than 1300 bodies of executed persons (Angetter, 2000). Also, it was likely that these victims' bodies had been used for the creation of the atlas. How was this possible?

The traditional sources of anatomical body procurement changed decisively under the National Socialist regime. Before 1933, these legally defined sources had been nearly exclusively so-called unclaimed bodies, that is, bodies of persons who died in public institutions and whose families did not claim them for burial. Among these traditional sources were deceased psychiatric patients, persons who committed suicide, deceased prisoners, and among those executed persons. After 1933, increasing numbers of victims of the National Socialist regime among these sources. Among the psychiatric patients were persons killed within the socalled "euthanasia" program. Among the suicides were rising numbers of Jewish citizens. Among the deceased prisoners were more political prisoners due to the new legislation; more deaths due to violence, especially in the Gestapo prisons. And there were many so-called "natural deaths" in the new network of camps: concentration camps and decentralized camps for forced laborers and prisoners of war. And finally, there were exponentially rising numbers of bodies of executed persons. While during the Weimar Republic, between 1919 and 1933, only about 200 men and no women had been executed, these numbers now rose to more than 30,000 following civilian and military trials. There were now also women, some of whom were pregnant.

Based on numbers from existing case studies of individual anatomical departments, the total body supply for the 31 German anatomical departments can be estimated. A conservative estimate lies at about 30-35,000 bodies. The total number of all Victims of the regime used in anatomy remains unclear. An evidence-based estimate from the anatomical department of Tübingen states that $2 / 3$ of the bodies stemmed from victims. All of the anatomical departments used the bodies of the executed, independent of the political convictions of the anatomists. The official instrument of execution was the guillotine. Among the victims were at least 3938 bodies of executed persons from 20 departments that are documented so far. Most of the names are known, but biographies still have to be reconstructed for a full memorialization of these victims. The final number of the executed victims will be much higher, as much information is still missing (Hildebrandt, 2013b).

In the last decade or two, a focus on systematic victim identification has developed (Lang, 2007), for example on the victims on Hermann Stieve's list (Hildebrandt 2013c). In 1946 Hermann Stieve produced a list with the names of his research "subjects," as demanded by the Soviet Military Government. This list was only fragmentary, as the body register had been "lost" after the war. Copies of this document are held in archives in Berlin. At the same time, the memorial site for the German resistance has collected information on the National Socialist victims executed at Berlin Plötzensee. In combining information from these documents, it was possible identify the names of 174 women and 8 men on the list. Libertas Schulze-Boysen was number 37 . 


\section{The Women on Stieve's list}

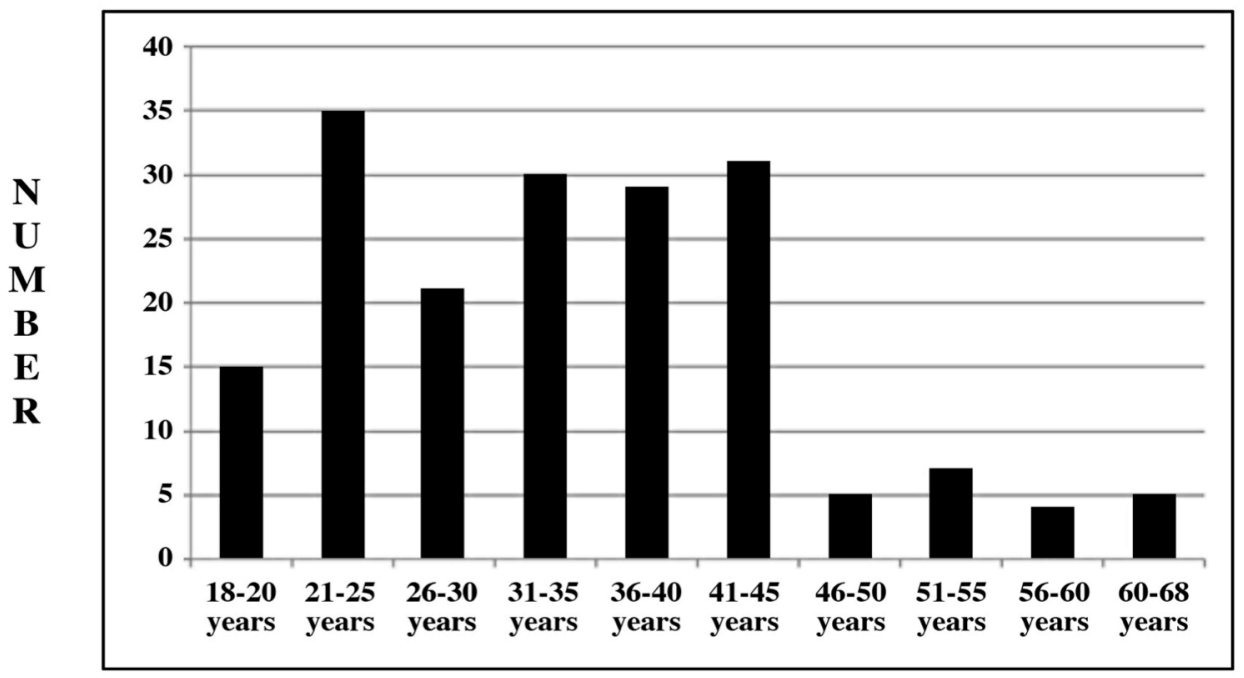

\section{Age distribution of persons on Stieve's list, N=182, Berlin 1935-1944}

Table 1. Women on Stieve's list were mostly of reproductive age, but there were also women of postmenopausal age for whom Stieve also had a research interest. Image credit: Clinical Anatomy, John Wiley and Sons, license number 5036540034755.

The persons on Stieve's list were mostly of reproductive age, but there were also women of postmenopausal age or whom Stieve also had a research interest [Table 1]. Two thirds of the women were German, with larger groups of Polish, Czech and French persons, too. Some of them were of Jewish descent.

Almost half of the women had been sentenced to death for treason, a quarter for minor crimes like looting or mail-theft, and another sizable group of so-called "subversion of the regime". The women were home makers, social workers, administrators, political activists, lecturers, forced laborers, artists, tailors, and dancers. They all shared the fate of being sentenced to death by a court and being executed. None of them knew what was going to happen with their bodies after their death.

All of these victims' bodies were used for anatomical purposes in education and research, leading to clear stages of an ethical transgression (Hildebrandt, 2013a; Hildebrandt, 2016). It is largely unknown, what the confrontation with the bodies of the victims did to a whole generation of physicians, who learned anatomy from these victims' bodies. Very few of them talked about their experiences after the war, and even fewer did so publicly. One of the few who spoke about his experiences was Hoimar von Ditfurth, who began his medical studies in Berlin in 1940. Von Ditfurth remembered: "We students knew, on whose human remains our gain of anatomical knowledge rested [...]." Especially in the urban centers, citizens had to notice the bright red posters distributed all over, which announced executions and the reason for the verdict. He was also one of the very few who openly reflected on their experiences during the dissection courses in the war. Fifty years later he asked himself: "Did this knowledge alone $[\ldots]$ also mean that we were complicit? The answer to this question isn't easy, but I tend to think that it is: yes." There were no similar public voices of reflection among the anatomists who used the bodies of executed persons for their work.

Max Clara, chairman of anatomy at the University of Leipzig and Munich, went one step further from the mere use of bodies of the dead, as Andreas Winkelmann and Thorsten Noack (Winkelmann and Noack, 2010) have pointed out from a paper Clara published in 1942. Clara wrote: "The material evaluated in the current study stems from 15 apparently healthy adult individuals of different ages, who without 
exception all died of a sudden death after varying periods of imprisonment; a 333/4 year old male individual received 1 pill of Cebion (Merck) four times daily for the last 5 days before his death." Clara had realized that he could gain access to prisoners on death row before their death, and thus started exploiting this opportunity for his own purposes. He had Vitamin C secretly administered to prisoners for five days before their deaths. By doing this Clara crossed a distinct boundary of the traditional anatomical method: he moved from work with the dead to work with the "future dead," that is: to human experimentation.

This transgression is even more apparent in Johann Paul Kremer. This professor of anatomy and SS officer from the University of Münster was detailed to Auschwitz in the fall of 1942. While he had not entered the camp in search of "research material," he quickly realized the "research potential" of the situation. He had worked previously on the effect of hunger in amphibians.

During his duties, which included selections at the train ramp and especially on the prison sick ward, he realized a "new opportunity" to continue his work on humans. He selected prisoners who looked "interesting" to him and made sure to be present at these prisoners' executions. In the execution chamber he questioned them about clinical details before their murder by intracardiac phenol injection, then removed tissues from their bodies and sent them to Münster. All this he recorded in his diary, which was found by the British Military searching his home after the war. This diary became the first document proving the involvement of physicians in medical experiments in the camps. Kremer was put on trial in Poland, sentenced to death, but released to Germany 10 years later, where he was again put on trial. He died of natural causes in 1965.

August Hirt was the mastermind of the anatomical experiment with the "future dead". He was the chair of anatomy at the Reichsuniversität Strassburg and performed inhumane poison-gas experiments on prisoners in the concentration camp Struthof/Natzweiler with the aid of the Ahnenerbe, the SS organization studying "race" and heredity. He also planned an anatomical-anthropological experiment: a "Jewish skeleton collection", for which he had living prisoners selected in Auschwitz by the SS anthropologists Bruno Beger and Hans Fleischhacker in summer of 1943. The prisoners were then transported to Natzweiler, gassed there with Cyanide salts, which Hirt had handed to the camp commander, and their bodies transported to the anatomical department in Strassburg, where the bodies

\section{Photographs of original illustrations from Dr. Sabine Hildebrandt's March 2019 visit to Elsevier in Munich}

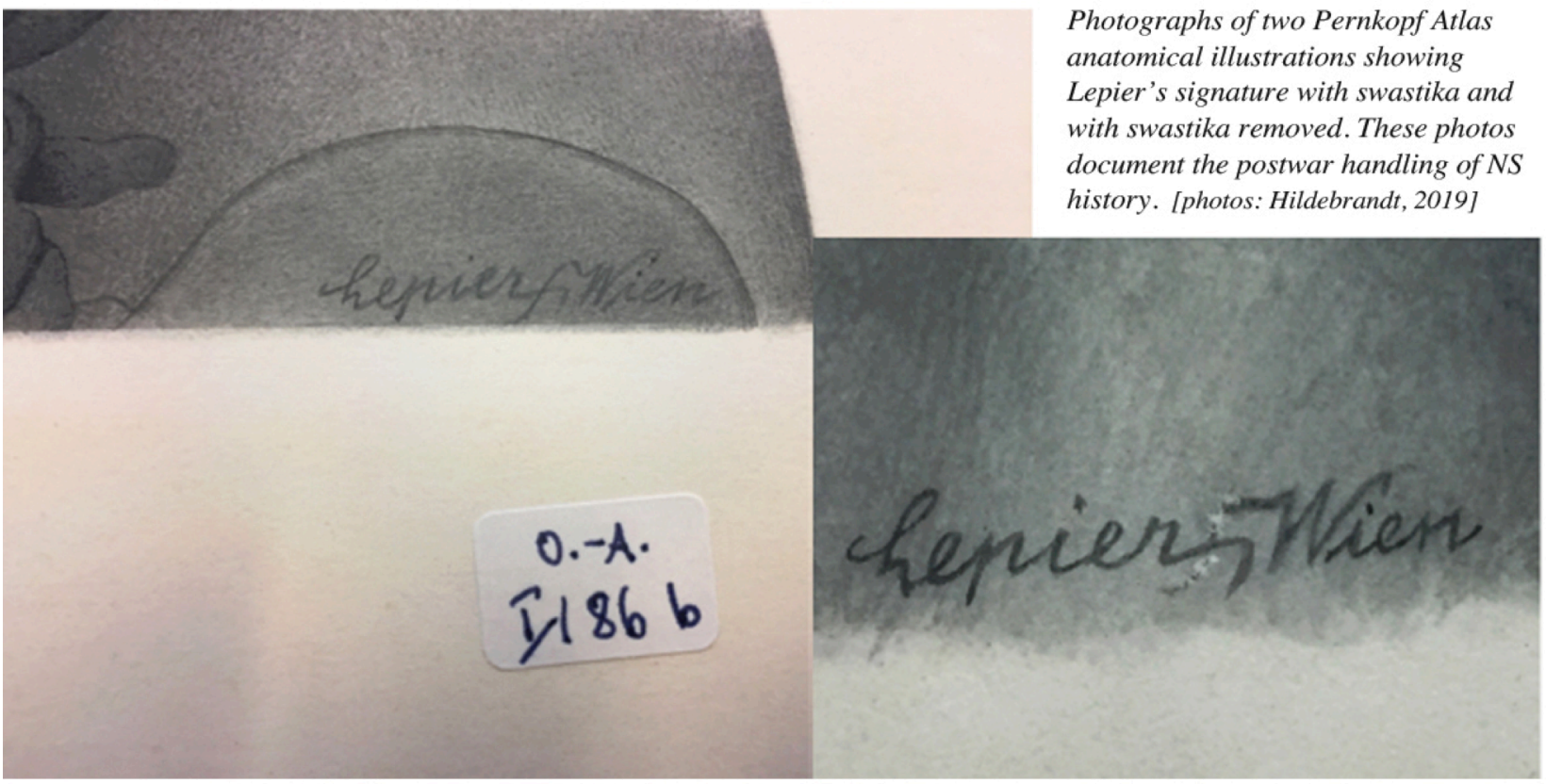

Figure 2. Color pigments appeared to have been scratched or "picked" away with a very fine needle from the vertical bar of the Swastika. Image credits: Medical University of Vienna, MUW-ZE-003250-0005-0466-DETAIL-Hakenkreuz, MUW-ZE-0032500005-0032-DETAIL-Hakenkreuz. 
were discovered at the liberation of the city in November 1944. After the war he was the only anatomist named in the Nuremberg Doctors' Trial in $1946 / 47$ and was indicted in absentia as a murderer in Metz/Alsace in 1952. At that time it was discovered that he had committed suicide in the summer of 1945 (Lang, 2013).

There are many continuities and legacies from this history (Caplan, 1992), which can be summarized with the phrase "Books, Bones and Bodies." Charlotte Pommer remained the only voluntarily "retired" anatomist. Only few German and Austrian anatomists lost their positions after the war. Their research on bodies of National Socialist victims was published in journals that were read around the world and is integrated into the general canon of anatomical knowledge (Hildebrandt, 2013a). Books by these anatomists continue to be used. The most prominent example is the Pernkopf atlas (Hildebrandt, 2006; Hartsock, 2019; Hildebrandt and Seidelman, 2018; Mages and Lohr, 2017).

In 1952 the Austrian press celebrated the publication of the third volume of the Pernkopf atlas as a "New achievement on a global scale for Austrian science". The newspaper Die Presse wrote on March 16, 1952: " [with this the publisher Urban \& Schwarzenberg] succeeded in creating a true masterpiece [...] Here came about not only a scientifically flawless, indeed outstanding work, but also did 10 years of ceaseless effort, overly fraught with difficulties, sacrifices and stress, reach their goal."

Part of this effort was anatomist Werner Platzer, who joined Pernkopf's team after the war. In the 1960s Platzer became chair of anatomy in Innsbruck, Austria, and in the 1990s he was involved in the Pernkopf controversy.

At that time, he also served as editor of the 3rd edition of the atlas. Following Yad Vashem's inquiry he explained in a 1995 letter to the president of Innsbruck University that his institute held no specimens derived from the bodies of "Nazi victims", and that the 3. Edition of the Pernkopf atlas, of which he was editor, did not include any signatures that pointed to the past. With reference to Lepier and the Swastika signature he declared that these had been destroyed.
While it was known that in printings of the same 1963 American edition the Swastikas had been retouched, there were also reports that the originals had been manipulated. To clarify this situation, this author decided to visit the publisher Elsevier in Munich in March 2019. Elsevier was the copyright holder of the atlas and still held some of the originals at that time. The originals demonstrated an example of the pervasive manner of the postwar handling of National Socialist history: not only a white-washing, but indeed a white "picking", as the color pigments had appeared to be scratched away with a very fine needle from the vertical bar of the Swastika, see Figure 2 [photos: Hildebrandt, 20. March 2019].

In 1998 Professor Platzer gave an interview to $\mathrm{CNN}$ in the anatomy institute in Innsbruck. He appeared in his office with glass containers holding 2 head specimens that he had dissected for the Pernkopf atlas and brought from Vienna to Innsbruck. The interviewer asked, "Could these be specimens from executed Nazi victims?" and Prof. Platzer answered, "That's possible, I don't know." These specimens could not be found in a subsequent investigation of the Innsbruck anatomical collection.

Also, bodies of NS victims were used for many years longer in teaching and research. While specimens of NS origin were officially removed from collections in the early 1990s, more are still being found. Among the currently on going investigations are:

- Freie Universität Berlin/Kaiser-Wilhelm-Institut anthropology

- Univ. Strasbourg "History of the Medical Faculty of the Reichsuniversität Strassburg 1941-1945"

- Max-Planck-Society specimens from victims

- Blechschmidt collection of embryos Göttingen

- Oscar and Cecile Vogt Neuroanatomy Collection

Düsseldorf

- Anatomy during National Socialism at the University of Innsbruck

- Anatomy during National Socialism at the University of Hamburg

- Anatomical collection Friedrich-Alexander University Erlangen-Nürnberg. 
The Berlin historical investigations (Pollock and Cyrus, 2018) were started in response to an incident in the summer of 2014, when during routine excavations on a property of the Free University of Berlin Dahlem, bone fragments were found. This excavation happened in the vicinity of the former Kaiser-Wilhelm-Institute for Anthropology, Human Heredity and Eugenics (KWIA), which during National Socialist times had been directed by Otmar Freiherr von Verschuer, an internationally respected twin-researcher. He was also the mentor of Josef Mengele, who had sent specimens from Auschwitz to von Verschuer. This historical significance was overlooked and the bone fragments were handled routinely and incinerated. Protests by historians, among them Götz Aly, followed.

Just around the same time it was discovered that brain specimens and documents on potential victims of the "euthanasia" program were still kept in archival collections of various Max-Planck Institutes, despite the fact that previous announcements by the institutes had stated that such specimens had all been removed from the collections and buried in a Christian cemetery in Munich (Weindling, 2012; Seidelman, 2012; MPI brain research, 2015). These events motivated a group of medical historians to discuss the necessity of a formal protocol of standard for the handling of human remains from potential Holocaust victims. While there exist several guidelines and recommendations concerning collections and incidental discoveries of human remains from the National Socialist period (e.g.

Bundesärztekammer, 2003; Deutscher Museumsbund, 2013), these are often discipline-bound and do not necessarily include the voice of victims of the Holocaust, especially the main group of people persecuted, the Jews. Thus, an interdisciplinary and international symposium was organized at Yad Vashem, the Holocaust Martyrs Authority in Jerusalem in May 2017, with experts on the Jewish perspective, archaeologists, anthropologists and medical historians.

The result was the "Vienna Protocol: Recommendations How to Deal With Holocaust Era Human Remains," including a Responsum by Rabbi Joseph Polak (Polak, 2018, in collaboration with Prof. Michael Grodin). Without reading the full text here, it can be pointed out that these recommendations prioritize the identification, burial and documentation of the remains of individual victims, in order to aid their commemoration.
The recommendations also include the Vienna Protocol: For when Jewish or possibly-Jewish human remains are discovered, by Rabbi Polak of Boston. The "Vienna Protocol" presents a scholarly legal and ethical evaluation in the form of a Responsum in the Jewish tradition. It also explores the potential use of data derived from victims of the Holocaust, data such as the Pernkopf images. Rabbi Polak concludes that use of these images is permitted by most authorities to help save life (piku'ach nefesh), but this use requires making it known to one and all just exactly what these drawings are. In this way, the dead are accorded at least some of the dignity to which they are entitled (Elie Wiesel Center for Jewish Studies, 2017; Yee et al. 2019a, 2019b; Caplan, 2019).

The recommendations from Yad Vashem with the Vienna Protocol are formulated in a manner that makes them widely applicable beyond the Jewish context. There are clear parallels to questions about the handling of human remains from other contexts of human rights abuse, for example, the vanished orphans of the former Mother and Baby Home, Tuam, County of Galway, Ireland.

The National Socialist history of anatomy also shines a clear light on current critical questions in anatomy, as unethical handling of anatomical bodies still exists, as a series of investigations by Reuters on the unethical business practices of private for-profit body brokers reveals (Reuters, 2017; Champney et al. 2019). The legacy of this history for researchers is to always ask: Where do the bodies come from? Where do the tissues come from? Where do the images and data come from? Where does the knowledge come from?

Anatomists used the bodies of victims of the National Socialist regime in education and research, committing ethical transgressions that included a paradigm shift from work with the dead to work with the "future dead." The victims' remains were buried in unmarked graves, or "lost" in collections, without names. Thus, anatomists were complicit in the complete physical annihilation and destruction of the memory of victims of the National Socialist regime. It is a duty and a privilege to restore the biographies and enable the memorialization of the victims of anatomy during the National Socialism, because "Forgetting them would be the victims' final annihilation" (Lang, 2007). 


\section{References}

Angetter DC. Anatomical science at the University of Vienna 1938-45. Lancet. 2000; 355:1445-57.

Bundesärztekammer. Arbeitskreis "Menschliche Präparatesammlungen". 2003. Empfehlungen zum Umgang mit Präparaten aus menschlichem Gewebe in Sammlungen, Museen und öffentlichen Räumen.

Deutsches Ärzteblatt. 8:378-383.

Caplan AL (ed.). When Medicine Went Mad: Bioethics and the Holocaust. Totowa: Humana Press; 1992. Caplan AL. Commentary: Consulting evil. Surgery May 2019;165(5):870.

Clara, Max. 1942. Beiträge zur Histotopochemie des Vitamin C im Nervensystem des Menschen. Zeitschrift für miskroskopisch-anatomische Forschung 52:359392.

Champney TH, Hildebrandt S, Jones DG, Winkelmann A. Bodies R Us: Ethical views on the commercialization of the dead in medical education and research. Anat Sci Educ. 2019;12, 317-325.

Deutscher Museumsbund. 2013. Recommendations for the Care of Human Remains in Museums and Collections. https://www.museumsbund.de/wpcontent/uploads/2017/04/2013-recommendations-forthe-care-of-human-remains.pdf. Published 2013. Accessed February 4, 2020.

Elie Wiesel Center for Jewish Studies.

Recommendations for the discovery of Jewish remains project.

http://www.bu.edu/jewishstudies/files/2018/08/HOWTO-DEAL-WITH-HOLOCAUST-ERAREMAINS.FINAL_pdf. Published November 2017. Accessed February 10, 2020.

Gollwitzer H, Kuhn K, Schneider, R (eds.). 1955. Du hast mich heimgesucht in der Nacht. Abschiedsbriefe und Aufzeichnungen des Widerstandes 1933-1945. Zweite Auflage. München: Chr. Kaiser Verlag.
Grüttner, Michael, and Sven Kinas. 2007. Die Vertreibung von Wissenschaftlern aus den deutschen Universitäten 1933-45. Vierteljahreshefte für Zeitgeschichte 55(1):123-186.

Hartsock J, Beckman E. 2019. A human paradox: the Nazi legacy of the Pernkopf atlas. Conatus. 4:317-339. Hildebrandt S. 2006. How the Pernkopf Controversy Facilitated a Historical and Ethical Analysis of the Anatomical Sciences in Austria and Germany: A Recommendation for the Continued Use of the Pernkopf Atlas. Clin Anat. 19:91-100.

Hildebrandt S. 2013a. Research on Bodies of the Executed in German Anatomy: An Accepted Method that Changed During the Third Reich. Study of Anatomical Journals from 1924 to 1951. Clin Anat. 26:304-326.

Hildebrandt S. 2013b. Current status of identification of victims of the National Socialist regime whose bodies were used for anatomical purposes. Clinical Anatomy. 27:514-536.

Hildebrandt, Sabine. 2013c. The Women on Stieve's List: Victims of National Socialism whose Bodies were Used for Anatomical Research. Clinical Anatomy. 26:321.

Hildebrandt S. 2016. The Anatomy of Murder: Ethical Transgressions and Anatomical Science during the Third Reich. New York: Berghahn Books.

Hildebrandt S, Seidelman WE. 2018. To use or not to use: The legitimacy of using unethically obtained scientific human tissue from the National Socialist era. Wie Klin Woch. 130(3):S228-S231.

Israel HA, Seidelman WE. 1996. Nazi Origins of an anatomy text: the Pernkopf Atlas. JAMA. 276(20), 1633 Lang HJ. 2007. Die Namen der Nummern: Wie es gelang, die 86 Opfer eines NS-Verbrechens zu identifizieren. Überarbeitete Ausgabe. Frankfurt am Main: S. Fischer Verlag.

Lang HJ. 2013. August Hirt and "Extraordinary Opportunities for Cadaver Delivery" to Anatomical 
Institutes in National Socialism: a Murderous Change in Paradigm. Annals of Anatomy 195:373-380.

Mages K, Lohr LA. 2017. Body of evidence: integrating Eduard Pernkopf's Atlas into a librarian-led medical curriculum. J Med Lib Ass. 105(2),173-178.

MPI brain research. 2015. Full transparency about institute's history - new traces of Third Reich atrocities discovered. http://brain.mpg.de/newsevents/news/news/archive/2015/april/article/additionaltraces-of-former-institute-directors-crimesdiscovered.html. Published April 9, 2015. Accessed 2. February 2, 2020.

Orth, Barbara. 2013. Gestapo im OP: Bericht der Krankenhausärztin Charlotte Pommer. Berlin: LukasVerlag

Polak JA. 2018. Vienna Protocol for when Jewish or possibly-Jewish human remains are discovered. Wie Klin Woch. 130(3):S239-S243.

Pollock S, Cyrus G. 2018. Skelettreste unklarer Herkunft: Untersuchungen in Berlin-Dahlem. In: Archäologische Gesellschaft in Berlin und Brandenburg e.V. (Hrsg.): Archäologie in Berlin und Brandenburg 2016. Stuttgart: Konrad-Theiss Verlag, 140-142.

Reuters. 2017.

Reuters investigates: The body trade. https://www.reuters.com/investigates/section/usabodies/. Published 2017. Accessed February 3, 2020.

Seidelman WE. 2012. Dissecting the history of anatomy in the Third Reich - 1989-2010: A personal account. Ann Anat 194:228-236.

Weindling PJ. 2012. "Cleansing" anatomical collections: The politics of removing specimens from anatomical collections 1988-1992." Ann Anat 194:237242.

Weissmann G. 1985. Springtime for Pernkopf. Reprinted 1987 in: Weissmann, Gerald (ed.): They all laughed at Christopher Columbus. New York: Times Books, 48-69.
Williams DJ. 1988. The History of Eduard Pernkopf's Topographische Anatomie des Menschen. J Biocomm. 15(2),2-12.

Winkelmann A, Noack T. 2010. The Clara Cell: a "Third Reich Eponym?" European Respiratory Journal 36:722-727.

Winkelmann A, Schagen U. 2009. Hermann Stieve's Clinical-Anatomical Research on Executed Women During the "Third Reich. Clinical Anatomy 22(2):163171.

Yee A, Coombs D, Hildebrandt S, Seidelman WE, Coert H, Mackinnon SE. 2019a. Nerve surgeons' assessment of the role of Eduard Pernkopf's atlas of topographical and applied human anatomy in surgical practice. Neurosurgery. 84(2), 491-498 .

Yee A, Zubovic E, Yu J, Shuddhadeb R, Hildebrandt S, Seidelman WE., Polak JA., Grodin, MA, Coert H, Brown D, Kodner IJ, Mackinnon SE. 2019b Ethical considerations in the use of Pernkopf's atlas of anatomy: A surgical case study. Surgery 165(5), 860867.

\section{About the Author}

Sabine Hildebrandt is an associate professor of pediatrics in the Division of General Pediatrics, Department of Pediatrics at Boston Children's Hospital, and a lecturer on Global Health and Social Medicine at Harvard Medical School. She teaches anatomy and history of anatomy at Harvard Medical School and Harvard College. Her book "The Anatomy of Murder: Ethical Transgressions and Anatomical Science during the Third Reich" (Berghahn Books 2016) is the first systematic study of anatomy during National Socialism. The biography of Jewish physician refugee Käthe Beutler was published by Hentrich\& Hentrich in 2019. She is currently researching the history of the Anatomical Institute as a member of the Historical Commission on the Reichsuniversität Strassburg 194144. She is also co-editor of "Recognizing the Past in the Present: Medicine before, during and after the Holocaust" to be published by Berghahn Books in 2021. 
Sabine Hildebrandt, M.D.

Associate Professor of Pediatrics;

Lecturer on Global Health and Social Medicine

Boston Children's Hospital, Harvard Medical School

Contact: Sabine.Hildebrandt@childrens.harvard.edu

\section{Licensing}

The author has chosen to license this content under a Creative Commons Attribution, NonCommercial, NoDerivatives 4.0 International License.

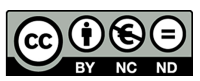

Authorization for publication of images from Pernkopf's atlas has been granted for use in this article only. The atlas images must remain within the context of this article for open-access, scholarship and educational use. The atlas images in this article may not be removed from this article, nor reproduced, nor distributed, outside of the context of this article, for scholarly, education or commercial purposes, without the expressed permission of the Josephinum.

\section{Image Credits}

The Journal of Biocommunication wishes to thank the Josephinum and the Medical University of Vienna for approving the publication of Pernkopf atlas images that are used within this Special Issue. These images may appear on the cover, in the Table of Contents, and as figures within articles and are acknowledged with the following image credit:

Josephinum - Ethik, Sammlungen und Geschichte der Medizin, MedUni Wien

Josephinum - Ethics, Collections and History of Medicine, MedUni Vienna

\section{Conflict of Interest Statement}

The Journal of Biocommunication Management Board and Editors believe that transparency in academic research is essential. Our JBC authors are now required to disclose any possible conflict of interest when submitting a manuscript. In accordance with the Journal of Biocommunication's editorial policy, no potential conflict of interest has been reported or declared by this author. 